\title{
Pengaruh Karakteristik Individu dan Karakteristik Pekerjaan Terhadap Komitmen Organisasi Karyawan Pada PDAM Lematang Enim Kabupaten Muara Enim
}

\author{
Yuyun S ${ }^{1}$, Tri Darmawati ${ }^{2}$ \\ ${ }^{1}$ Manajemen, F. Ekonomi dan Bisnis UPGRI Palembang, yuyunsapti@gmail.com \\ 2Manajemen, F. Ekonomi dan Bisnis UPGRI Palembang, tridarmawati@univpgri-palembang.ac.id
}

\begin{abstract}
ABSTRAK
Penelitian ini bertujuan untuk mengetahui pengaruh karakteristik individu dan karakteristik pekerjaan terhadap komitmen organisasi karyawan pada PDAM Lematang Enim Kabupaten Muara Enim. Metode yang digunakan dalam penelitian ini adalah metode kuantitatif dengan populasi sebanyak 133 orang. Sampel yang digunakan dalam penelitian ini menggunakan teknik sampel dengan rumus slovin sehingga diperoleh sampel sebanyak 57 responden. Teknik analisis data yang digunakan dalam penelitian ini, yaitu analisis regresi linier berganda, analisis koefisien korelasi, analisis koefisien determinasi, uji $t$, dan uji $f$ dengan menggunakan program spss versi 22.Dari hasil pengujian uji $t$ diperoleh nilai signifikan karakteristik individu $\left(X_{1}\right)$ sebesar $0,023<0,05$ maka Ho ditolak dan Ha diterima yang berarti secara parsial karakteristik individu berpengaruh signifikan terhadap komitmen organisasi karyawan. Sedangkan nilai signifikan karakteristik pekerjaan $\left(X_{2}\right)$ sebesar $0,000<0,05$ maka Ho ditolak dan Ha diterima yang berarti secara parsial karakteristik pekerjaan berpengaruh signifikan terhadap komitmen organisasi karyawan. Dan hasil uji f diperoleh nilai signifikan sebesar $0,000<0,05$ maka Ho ditolak dan Ha diterima sehingga dapat disimpulkan bahwa secara simultan karakteristik individu $\left(\mathrm{X}_{1}\right)$ dan karakteristik pekerjaan $\left(\mathrm{X}_{2}\right)$ berpengaruh signifikan terhadap komitmen organisasi karyawan pada PDAM Lematang Enim Kabupaten Muara Enim.
\end{abstract}

Kata Kunci : Karakteristik Individu, Karakteristik Pekerjaan, Komitmen Organisasi Karyawan

\begin{abstract}
This study aims to determine the effect of individual characteristics and job characteristics on employee organizational commitment at PDAM Lematang Enim, Muara Enim Regency. The method used in this study is a quantitative method with a population of 133 people. The sample used in this study used a sampling technique with the Slovin formula in order to obtain a sample of 57 respondents. Data analysis techniques used in this study, namely multiple linear regression analysis, correlation coefficient analysis, analysis of the coefficient of determination, $t$ test, and $f$ test using the SPSS version 22 program. From the results of the $t$ test, it was found that the significant value of individual characteristics (X1) was $0.023<0.05$, so Ho was rejected and Ha was accepted, which means that partially individual characteristics have a significant effect on employee organizational commitment. While the significant value of job characteristics (X2) is $0.000<0.05$, so Ho is rejected and $\mathrm{Ha}$ is accepted, which means that partially job characteristics have a significant effect on employee organizational commitment. And the results of the f test obtained a significant value of 0.000 $<0.05$, so $\mathrm{Ho}$ is rejected and $\mathrm{Ha}$ is accepted, so it can be concluded that simultaneously individual characteristics (X1) and job characteristics (X2) have a significant effect on employee organizational commitment at PDAM Lematang Enim, Muara Enim Regency.
\end{abstract}

Keywords: Individual Characteristics, Job Characteristics, Commitment Employee Organization

\section{A. PENDAHULUAN}

Kerja karyawan dapat dikatakan dengan baik jika mereka menjalankan salah satu visi dan misi perusahaan.
Pencapaian visi dan misi tersebut tidak lain hanya untuk mengelola Sumber Daya Manusia yang berpotensi baik agar dapat meningkatkan komitmen 
kerja maupun organisasi karyawannya di perusahaan tersebut. Setiap karyawan yang bekerja di suatu perusahaan atau organisasi tersebut haruslah mempunyai karakteristik dan komitmen tersendiri dalam bekerja, karena apabila suatu perusahaan jika karyawannya tidak mempunyai suatu karakteristik atau komitmen dalam bekerja, maka tujuan dari suatu perusahaan atau organisasi tersebut tidak akan tercapai.

Fahmi (2014:51) menjelaskan bahwa karakteristik adalah sesuatu yang tumbuh sejalan dengan waktu dan telah menempa serta membentuk sikap seseorang, yang selanjutnya itu memberi pengaruh pada setiap keputusan yang dibuat oleh orang tersebut.

Sulle dan Sefullah (2010:216) karakteristik individu dapat dijelaskan bahwa dengan cara memandang sumber daya manusia karyawan, juga berarti memandang bahwa mereka sebagai tenaga kerja perusahaan, serta merupakan individu-individu yang memiliki karakteristiknya masingmasing.

Bintoro dan Daryanto (2017:81) mengemukakan karakteristik pekerja pada kenyataannya para anggota organisasi merupakan faktor pengaruh yang paling penting karena perilaku merekalah yang dalam jangka panjang akan memperlancar atau merintangi tercapainya tujuan organisasi.

Robbins dan Coulter (2010:40) mendefinisikan bahwa komitmen organisasi merupakan derajat dimana seorang karyawan mengidentifikasikan dirinya dengan organisasi tertentu beserta tujuannya dan berkeinginan untuk mempertahankan keanggotaannya di dalam organisasi tersebut.

Berdasarkan penelitian terdahulu yang telah dilakukan oleh Dewi, dkk (2019), dengan hasil penelitian menunjukkan bahwa karakteristik pekerjaan berpengaruh positif dan signifikan terhadap komitmen organisasi. Sedangkan penelitian terdahulu yang dilakukan oleh Kuhuparuw (2017), dengan hasil pengujian hipotesis menyatakan bahwa variabel karakteristik individu sangat berpengaruh positif dan signifikan terhadap komitmen organisasi.

\section{B. KAJIAN TEORI}

1) Karakteristik Individu

Menurut Thoha (2011:34)

berkaitan dengan karakteristik individu bahwa individu membawa ke dalam tatanan organisasi kemampuan, kepercayaan pribadi, pengharapan kebutuhan, dan pengalaman masa lalunya. Ini semuanya adalah karakteristik yang dipunyai individu, dan karakteristik ini akan dibawa olehnya manakala ia akan memasuki sesuatu lingkungan baru, yakni organisasi atau lainnya.

Menurut Torang (2016:53-77) faktor yang mempengaruhi karakter individu dalam organisasi, yaitu:

a. Kompetensi

Kompetensi adalah karakteristik individu yang mendasari kinerja atau perilaku didalam organisasi.

b. Motivasi

Motivasi adalah energi yang menggerakkan individu untuk berusaha mencapai tujuan yang diharapkan,

c. Kepemimpinan

Kepemimpinan adalah seorang pimpinan harus memiliki kompetensi atau pengetahuan (manajerial dan strategi) yang lebih, berperilaku yang baik, mampu mempengaruhi dan mengarahkan orang lain, harus mengambil keputusan, bertanggung jawab, baik dalam penyampaian ide, bijak, mengayomi, dan memberi motivasi. 
d. Konflik

Konflik organisasi dapat disebabkan oleh adanya kompetisi, perbedaan, pertentangan, klass, dan perselisihan.

Sariningtyas dan Sulistiyani (2016:59-60) indikator Karakteristik individu yang digunakan dalam penelitian ini, yaitu:

a. Kepribadian

Kepribadian adalah jumlah total dan cara-cara seorang individu beraksi atas dan berinteraksi dengan orang lain.

b. Kemampuan

Kemampuan adalah adalah kapasitas seseorang individu untuk melaksanakan beberapa kegiatan dalam suatu pekerjaan.

c. Sikap

\begin{tabular}{lrr} 
Sikap adalah paik & \multicolumn{2}{c}{ pernyataan- } \\
pernyataan evaluatif & baik \\
menyenangkan atau tidak \\
menyenangkan mengenai & objek, \\
orang atau peristiwa.
\end{tabular}

\section{2) Karakteristik Pekerjaan}

Bangun (2012:74) analisis pekerjaan adalah proses sistematis untuk mengenal karakteristik suatu pekerjaan. Berbagai informasi dapat diperoleh melalui analisis pekerjaan mencakup tugas-tugas, wewenang, dan tanggung jawab yang dituntut suatu pekerjaan.

Bangun (2012:102-104) berikut komponen-komponen rancangan pekerjaan, yaitu:

a. Komponen Organisasional
Komponen
organisasional
merupakan rancangan dalam organisasi yang berkaitan dengan efisiensi.
b. Komponen Lingkungan
Komponen lingkungan, merupakan pengaruh lingkungan terhadap pencapaian tujuan organisasi yang sangat besar.
c. Komponen Perilaku

Komponen Perilaku dalam pekerjaan ini adalah otonomi, variasi, identitas tugas, dan umpan balik.

Bangun (2012:99-100) ada lima dimensi karakteristik pekerjaan dan digunakan sebagai indikator dalam penelitian ini , yaitu:

a. Keanekaragaman keterampilan, yaitu memperlihatkan sejauh mana suatu pekerjaan yang dapat diselesaikan untuk menuntut keberagaman keterampilan.

b. Identitas tugas, yaitu sejauh mana suatu pekerjaan yang mencakup elemen tugas yang dapat diidentifikasi untuk dikerjakan dari awal sampai akhir dengan hasil baik.

c. Keberartian tugas merupakan dimensi yang menunjukan sejauh mana suatu pekerjaan mempunyai pengaruh besar terhadap pekerjaan.

d. Otonomi adalah sejauh mana suatu pekerjaan memberikan kebebasan pekerjaannya.

e. Umpan Balik, yaitu mengukur sejauh mana suatu pekerjaan memberikan informasi baik atau buruk ke atas hasil pekerjaan individu dalam organisasi.

\section{3) Komitmen Organisasi}

Sutrisno (2011:296) komitmen organisasi merupakan sikap loyalitas pekerja terhadap organisasinya dan juga merupakan suatu proses mengekspresikan perhatian dan partisipasinya terhadap organisasi.

Wibowo (2016:433-435) faktor yang mempengaruhi komitmen organisasional sebagai berikut:

a. Keadilan dan Dukungan Komitmen efektif lebih tinggi pada organisasi yang memenuhi kewajibannya pada pekerja.

b. Nilai Bersama

Komitmen efektif menunjukan identitas orang pada organisasi, dan 
identifikasi mencapai tingkat tertinggi ketika pekerja yakin nilainilai mereka sesuai dengan nilainilai dominan organisasi.

c. Kepercayaan

Kepercayaan menunjukan harapan positif satu orang terhadap orang lain dalam situasi yang melibatkan risiko.

d. Pemahaman Organisasional

Pemahaman organisasional menunjukkan seberapa baik pekerja memahami organisasi.

e. Pelibatan Kerja

Pelibatan kerja meningkatkan komitmen efektif dengan memperkuat identitas sosial pekerja dengan organisasi.

Akbar, dkk (2017:34) menentukan beberapa indikator yang menjadi ukuran dari komitmen organisasional, yaitu:

a. Indikator dari komitmen afektif yang terdiri dari karakteristik pribadi dan pengalaman kerja.

b. Indikator dari komitmen kontinuitas yang terdiri dari besarnya dan atau jumlah investasi atau taruhan sampingan individu, dan persepsi atas kurangnya alternatif pekerjaan lain.

c. Indikator komitmen normatif adalah pengalaman individu sebelum berada dalam organisasi dan pengalaman sosialisasi selama berada dalam organisasi.

\section{METODE PENELITIAN}

Sugiyono (2016:24) metode penelitian pada dasarnya diartikan sebagai cara ilmiah untuk mendapatkan data dengan tujuan dan kegunaan tertentu. Metode yang dilakukan dalam dalam penelitian ini adalah metode kuantitatif. Sugiyono (2016:35-36) metode kuantitatif dapat diartikan sebagai metode penelitian yang berlandaskan pada filsafat positivisme, digunakan untuk meneliti pada populasi atau sampel tertentu, pengumpulan data menggunakan instrumen penelitian, analisis data bersifat statistik, dengan tujuan untuk menguji hipotesis yang telah ditetapkan.

\section{1) Variabel Penelitian}

Sugiyono (2016:96) variabel penelitian adalah suatu atribut, sifat, atau nilai dari orang, obyek, organisasi atau kegiatan yang mempunyai variasi tertentu yang ditetapkan oleh peneliti untuk dipelajari dan kemudian ditarik kesimpulannya.

Sugiyono (2016:96) terdapat dua variabel yang akan digunakan untuk diteliti, yaitu:

1. Variabel Independen (Variabel Bebas)

Variabel bebas adalah merupakan variabel yang mempengaruhi atau yang menjadi sebab perubahannya atau timbulnya variabel dependen (terikat). Variabel bebas (X) dalam penelitian ini, yaitu Karakteristik Individu sebagai (X1) dan Karakteristik Pekerjaan sebagai (X2)

2. Variabel Dependen (Variabel Terikat)

Variabel terikat merupakan variabel yang dipengaruhi atau yang menjadi akibat, karena adanya variabel bebas. Variabel terikat dalam penelitian ini, yaitu Komitmen Organisasi (Y).

\section{2) Populasi dan Sampel}

a. Populasi

Sujarweni (2019:80) populasi adalah keseluruhan jumlah yang terdiri atas objek atau subjek yang mempunyai karakteristik dan kualitas tertentu yang ditetapkan oleh peneliti untuk diteliti dan kemudian ditarik kesimpulannya. Dalam penelitian ini 
yang akan menjadi populasi, yaitu karyawan tetap PDAM Lematang Enim Kabupaten Muara Enim berjumlah 133 orang.

\section{b. Sampel}

Sujarweni (2019:81) sampel merupakanbagian dari sejumlah karakteristik yang dimiliki oleh populasi yang digunakan untuk penelitian. Karena populasi dalam penelitian ini berjumlah 133 orang dan lebih dari 100 orang, sehingga dalam penelitian ini menggunakan teknik sampel dengan rumus slovin sebagai berikut:

$$
\begin{aligned}
& n=\frac{\mathrm{N}}{1+\left(\mathrm{NX} e^{2)}\right.} \\
& \mathrm{n}=\text { Jumlah Sampel } \\
& \mathrm{N}=\text { Jumlah Populasi } \\
& \mathrm{e}=\quad \text { Prosentasi kelonggaran } \\
& \text { ketidakterikatan karena kesalahan } \\
& n=\frac{133}{1+\left(133.0,1^{2)}\right.}=\frac{133}{1+(133.0,01)} \\
& n=\frac{133}{2,53}=57 \text { Responden }
\end{aligned}
$$

Berdasarkan pendapat diatas, maka penulis mengambil sampel penelitian sebanyak 57 responden.

\section{3) Sumber Data}

Sujarweni (2019:89) sumber data yang digunakan dalam penelitian ini, yaitu sebagai berikut:

\section{Data Primer}

Data yang diperoleh dari responden melalui kuesioner, kelompok fokus, dan panel, atau juga data wawancara peneliti dengan nara sumber.

2. Data Sekunder

Data yang didapat dari catatan, buku, dan majalah berupa laporan keuangan publikasi, perusahaan, laporan pemerintah, artikel, buku-buku sebagai teori, majalah, dan lain sebagainya.

\section{4) Teknik Pengumpulan Data}

Teknik pengumpulan data yang dilakukan dalam penelitian ini, yaitu sebagai berikut:

\section{a. Kuesioner (Angket)}

Sugiyono (2016:230) kuesioner adalah teknik pengumpulan data yang dilakukan dengan cara memberi seperangkat pertanyaan atau pernyataan tertulis kepada responden untuk dijawabnya.

b. Dokumentasi
Gunawan
(2016

dokumentasi merupakan catatan peristiwa yang sudah berlalu yang berbentuk tulisan, gambar, atau karya monumental dari seseorang.

\section{5) Uji Coba Instrument}

\section{$>\quad$ Uji Validitas}

Sujarweni (2019:165) uji validitas merupakan digunakan untuk mengukur sah atau tidak validnya suatu kuesioner. Kuesioner dapat dikatakan sah atau valid jika pertanyaan pada kuesioner tersebut mampu mengungkapkan sesuatu yang akan diukur oleh kuesioner itu, uji signifikan dilakukan dengan membandingkan nilai $r$ hitung dengan nilai $r$ tabel untuk degree of freedom $(d f)=n-2$ ( $n$ adalah jumlah sampel) dan menggunakan tingkat signifikasi 0,05.

\section{$>\quad$ Uji Reliabilitas}

Sujarweni (2019:169) uji reliabilitas merupakan dilakukan terhadap item pertanyaan yang dinyatakan valid. Uji ini digunakan untuk mengukur suatu kuesioner yang merupakan indikator dari variabel atau konstruk. Suatu kuesioner dikatakan reliabel atau handal jika jawaban seseorang terhadap pernyataan 
adalah konsisten atau stabil dari waktu ke waktu. Suatu variabel dikatakan reliabel jika memiliki Cronbach Alpha> 0,60 .

\section{6) Asumsi Klasik}

\section{$>$ Uji Normalitas}

Sujarweni

\section{(2019:225)}

uji normalitas bertujuan untuk menguji apakah dalam model regresi, variabel terikat dan variabel bebas keduanya mempunyai distribusi normal ataukah tidak. Uji normalitas data dapat dilakukan dengan menggunakan uji Kolmogorov Smirnov satu arah. Pengambilan kesimpulan untuk menentukan apakah suatu data mengikuti distribusi normal atau tidak adalah dengan menilai nilai signifikannya. Jika signifikan $>0,05$ maka variabel berdistribusi normal dan sebaliknya jika signifikan $<0,05$ maka variabel tidak berdistribusi normal.

\section{$>\quad$ Uji Multikolinearitas}

\section{Sujarweni (2019:227) uji} multikolinearitas yang berarti ada hubungan linier yang sempurna atau pasti diantara beberapa semua variabel independen dari modal yang ada. Akibat adanya multikolinearitas ini koefisien regresi tidak tertentu, dan standarnya tidak terhingga. Dalam hal ini akan menimbulkan bias dalam spesifikasi. Uji multikolinearitas bertujuan untuk menguji apakah pada model regresi ditemukan korelasi antar variabel bebas. Pada model regresi yang baik, seharusnya tidak terjadi korelasi diantara variabel bebas. Metode untuk menguji adanya multikolinearitas dapat dilihat dari tolerance value atau inflation factor (VIF). Batas dari tolerance value $>0,1$ atau VIF lebih kecil dari 10, maka tidak terjadi multikolinearitas.

\section{$>\quad$ Uji Heteroskedastisitas}

\footnotetext{
Sujarweni (2019:226) uji heteroskedastisitas merupakan suatu
}

keadaan dimana varians dan kesalahan pengganggu tidak konstan untuk semua variabel bebas. Model regresi yang baik adalah tidak terjadi heteroskedstisitas. Uji ini dapat dilakukan dengan menggunakan uji Glejser yang berarti dengan menguji tingkat signifikasinya, pengujian ini dilakukan untuk merespon variabel $x$ sebagai variabel independen dengan suatu nilai absolut unstandardized residual regresi sebagai variabel dependen. Apabila hasil uji diatas level signifikan $(r>0,05)$ berarti tidak terjadi heteroskedastisitas, dan sebaliknya apabila level dibawah signifikan $(r<0,05) \quad$ berarti terjadi heteroskedastisitas.

\section{7) Teknik AnalisiS Data}

Sujarweni

(2019:121)

mendefinisikan analisis data diartikan sebagai upaya data yang sudah tersedia kemudian diola dengan statistik dan dapat digunakan untuk menjawab rumusan masalah dalam penelitian, teknik analisis data dalam penelitian ini terdiri dari:

\section{$>$ Analisis Regresi Linier \\ Berganda}

Sujarweni

(2019:227)

menjelaskan bahwa penelitian ini bertujuan untuk melihat pengaruh antar variabel independen dan variabel dependen dengan skala pengukuran atau rasio dalam suatu persamaan linier, dalam penelitian ini digunakan analisis regresi berganda yang diolah dengan perangkat lunak SPSS. Persamaan regresi yang digunakan dalam penelitian ini sebagai berikut :

$\mathrm{Y}=\alpha+\beta_{1} \mathrm{X}_{1}+\beta_{2} \mathrm{X}_{2}+\mathrm{e}$

Keterangan:

$\mathrm{Y}=$ Variabel Terikat Komitmen Organisasi Karyawan

$\alpha \quad=$ Konstanta 
$\beta 1=$ Koefisien Regresi

B2 = Koefisien Regresi

$\mathrm{X} 1=$ Variabel Bebas Karakteristik Individu

X2 =Variabel Bebas Karakteristik Pekerjaan

$\mathrm{e} \quad=$ Eror

\section{$>\quad$ Koefisien Korelasi}

Menurut Siregar (2013:337) koefisien korelasi merupakan bilangan yang menyatakan kekuatan hubungan antara dua variabel atau lebih juga dapat menentukan arah hubungan dari kedua variabel. Nilai korelasi $(r)=(-1 \leq$ $0 \leq 1$ ).

Untuk kekuatan hubungan, nilai koefisien korelasi berada antara -1 sampai 1, sedangkan untuk arah dinyatakan dalam bentuk positif $(+)$ dan negatif (-).

Misalnya:

a. Apabila $r=-1$ korelasi negatif sempurna, artinya terjadi hubungan bertolak belakang antara variabel $\mathrm{X}$ dan variabel $\mathrm{Y}$. Jika variabel $X$ naik, maka variabel $Y$ turun.

b. Apabila $r=1$ korelasi positif sempurna,artinya terjadi hubungan searah variabel $X$ dan variabel $Y$. Jika variabel $X$ naik, maka variabel $Y$ naik.

Tabel Tingkat Korelasi dan Kekuatan Hubungan

\begin{tabular}{|c|c|c|}
\hline No. & $\begin{array}{c}\text { Nilai } \\
\text { Korelasi }(\boldsymbol{r})\end{array}$ & $\begin{array}{c}\text { Tingkat } \\
\text { Hubungan } \\
\text { Sangat Lemah }\end{array}$ \\
\hline 1 & $0,00-0,199$ & Lemah \\
\hline 2 & $0,20-0,399$ & Cukup \\
\hline 3 & $0,40-0,599$ & Kuat \\
\hline 4 & $0,60-0,799$ & Sangat Kuat \\
\hline 5 & $0,80-0,100$ & S \\
\hline
\end{tabular}

Sumber : Siregar (2013:337)

$>\quad$ Koefisien Determinasi $\left(\mathbf{R}^{2}\right)$

Sujarweni

(2019:228)

menjelaskan

bahwa determinasi yang dinotasikan dengan $\mathrm{R}^{2}$ merupakan suatu ukuran yang penting dalam regresi. Determinasi $\left(R^{2}\right) \quad$ mencerminkan kemampuan variabel dependen. Tujuan analisis ini adalah untuk menghitung besarnya pengaruh variabel independen terhadap variabel dependen. Nilai $R^{2}$ menunjukkan seberapa besar proporsi dari total variasi variabel tidak bebas yang dapat dijelaskan oleh variabel penjelasnya. Semakin tinggi nilai $R^{2}$ maka semakin besar proporsi dari total variasi variabel dependen yang dapat dijelaskan oleh variabel independen.

\section{8) Kriteria Pengujian Hipotesis \\ $>\quad$ Uji t (Secara Parsial)}

Sujarweni

(2019:229)

mendefinisikan bahwa uji statistic $t$ menunjukkan seberapa jauh pengaruh satu variabel independen (X) atau variabel penjelas secara individual dalam menerangkan variabel dependen $(Y)$. Ketentuan penilaian hipotesis apabila nilai probabilitas signifikasinya lebih kecil dari 0,05 $(5 \%)$, maka dapat dikatakan suatu variabel independen $(X)$ berpengaruh signifikan terhadap variabel dependen (Y).

Kriteria :

1. Jika sig $<0,05$ maka Ho ditolak dan Ha diterima.

2. Jika sig $>0,05$ maka Ho diterima dan Ho ditolak.

\section{> Uji F (Secara Simultan)}

Sujarweni

(2019:228)

menjelaskan bahwa signifikasi model regresi secara simultan diuji dengan melihat nilai signifikasi (sig) dimana jika nilai sig dibawah 0,05 maka dapat dikatakan suatu variabel independen (X) berpengaruh terhadap variabel dependen (Y). Uji F-statistik digunakan untuk membuktikan adanya pengaruh antara suatu variabel independen (X) 
terhadap variabel dependen $(Y)$ secara simultan.

\section{Kriteria :}

1. Jika sig $<0,05$ maka Ho ditolak dan Ha diterima.

2. Jika sig $>0,05$ maka Ho diterima dan Ho ditolak.

\section{HASIL PENELITIAN \\ 1. Uji Normalitas}

Tabel Hasil Pengujian Normalitas

\begin{tabular}{|c|c|}
\hline Variabel & $\begin{array}{c}\text { Asymp. Sig. } \\
\text { (2-tailed) }\end{array}$ \\
\hline $\begin{array}{c}\text { Karakteristik } \\
\text { Individu }\end{array}$ & 0,103 \\
\hline $\begin{array}{c}\text { Karakteristik } \\
\text { Pekerjaan }\end{array}$ & 0,097 \\
\hline $\begin{array}{c}\text { Komitmen } \\
\text { Organisasi }\end{array}$ & 0,310 \\
\hline
\end{tabular}

Sumber : Data diolah 2020

Dari tabel diatas dapat diketahui bahwa nilai signifikan (Asymp.Sig 2tailed) untuk ketiga variabel Karakteristik Individu, Karakteristik Pekerjaan dan Komitmen Organisasi nilai signifikan lebih besar dari0,05, maka nilai variabel berdistribusi normal.

\section{Uji Multikolinieritas}

\section{Tabel Hasil Uji Multikolinieritas}

\begin{tabular}{|c|c|c|}
\hline \multirow{2}{*}{ Variabel } & \multicolumn{2}{|c|}{ Colinearity Statistics } \\
\cline { 2 - 3 } & Tolerance & VIF \\
\hline $\begin{array}{c}\text { Karakteristik } \\
\text { Individu }\end{array}$ & 0,920 & 1,087 \\
\hline $\begin{array}{c}\text { Karakteristik } \\
\text { Pekerjaan }\end{array}$ & 0,920 & 1,087 \\
\hline
\end{tabular}

Sumber : Data diolah 2020

Berdasarkan tabel diatas diketahui bahwa kedua variabel bebas diperoleh angka toleransi (tolerance) $0,920<0,10$ dan angka VIF 1,087 > 0,10 berarti dapat disimpulkan bahwa
Karakteristik Individu dan Karakteristik Pekerjaan tidak terjadi multikolinearitas.

\section{Uji Heteroskedasitas}

Tabel Hasil Uji Heteroskedasitas

\begin{tabular}{|c|c|c|}
\hline Variabel & $\begin{array}{c}\text { Sig. (2- } \\
\text { Tailed) }\end{array}$ & $\boldsymbol{\alpha}=\mathbf{5 \%}$ \\
\hline $\begin{array}{c}\text { Karakteristik } \\
\text { Individu }\end{array}$ & 0,493 & 0,05 \\
\hline $\begin{array}{c}\text { Karakteristik } \\
\text { Pekerjaan }\end{array}$ & 0,799 & 0,05 \\
\hline
\end{tabular}

Sumber : Data diolah 2020

Berdasarkan tabel diatas, dengan menggunakan uji Glejser dapat disimpulkan bahwa nilai signifikan variabel $X_{1}$ adalah $0,493>0,05$ artinya tidak terjadi heteroskedastisitas, dan nilai signifikan variabel $\mathrm{X}_{2}$ adalah 0,799 $>0,05$ artinya tidak terjadi heteroskedastisitas.

\section{Analisis Linier Berganda}

Tabel Hasil Uji Analisis Linier Berganda

\begin{tabular}{|c|c|c|c|}
\hline \multirow{2}{*}{ Variabel } & \multicolumn{2}{|c|}{$\begin{array}{c}\text { Understanadrized } \\
\text { Coefifficients }\end{array}$} & $\begin{array}{c}\text { Standarized } \\
\text { Coefficiens }\end{array}$ \\
\cline { 2 - 4 } & B & Std. Error & Beta \\
\hline (Constant) & 31,716 & 5,317 & \\
\hline $\begin{array}{c}\text { Karakteristik } \\
\text { Individu }\end{array}$ & -.228 & .098 & -.277 \\
\hline $\begin{array}{c}\text { Karakteristik } \\
\text { Pekerjaan }\end{array}$ & .507 & .109 & .554 \\
\hline \\
Sumber : Data diolah 2020
\end{tabular}

Berdasarkan hasil perhitungan dari tabel coefficients diatas terdapat hasil regresi linier berganda, yaitu nilai konstanta (a) sebesar 31,716, jika nilai $\mathrm{X}_{1}$ dan $\mathrm{X}_{2}$ nilainya 0 , maka konstanta 31,716 , nilai koefisien regresi $\left(b_{1}\right)$ sebesar -228, koefisien bernilai negatif artinya terjadi hubungan negatif antara karakteristik individu terhadap komitmen organisasi karyawan, dan nilai koefisien regresi $\left(b_{2}\right)$ sebesar 0,507 , koefisien bernilai positif artinya terjadi hubungan positif antara 
karakteristik pekerjaan terhadap komitmen organisasi karyawan. Berdasarkan nilai tersebut, diperoleh persamaan regresi berganda, sebagai berikut : $Y=31,716-228 X_{1}+$ $0,507 X_{2}+e$

\section{Analisis Koefisien Korelasi}

Tabel Hasil Uji Koefisien Korelasi

\begin{tabular}{|c|c|c|}
\hline $\mathbf{R}$ & $\begin{array}{c}\text { Adjusted } \\
\text { R Square }\end{array}$ & $\begin{array}{c}\text { Std. Error of the } \\
\text { Estimate }\end{array}$ \\
\hline .545 & 271 & 2.348 \\
\hline
\end{tabular}

Sumber : Data diolah 2020

Dapat dilihat dari tabel diatas bahwa nilai variabel koefisisen korelasi (R) antara Karakteristik Individu dan Karakteristik Pekerjaan terhadap Komitmen Organisasi Karyawan cukup atau mempunyai hubungan sebesar 0,545.

\section{Analisis Koefisien Determinasi}

\section{Tabel Hasil Uji Analisis Koefisien Determinasi}

\begin{tabular}{|c|c|c|}
\hline $\begin{array}{c}\mathbf{R} \\
\text { Square }\end{array}$ & $\begin{array}{c}\text { Adjusted } \\
\text { R Square }\end{array}$ & $\begin{array}{c}\text { Std. Error of } \\
\text { the Estimate }\end{array}$ \\
\hline 297 & 271 & 2.348 \\
\hline
\end{tabular}

Sumber : Data diolah 2020

Dari tabel diatas dapat diketahui bahwa nilai Koefisien Determinasi $R$ Square $\left(R^{2}\right)$ sebesar 0,297 atau $29,7 \%$ dan sisanya (100\% - 29,7\%) 0,703\% atau $70,3 \%$ dipengaruhi oleh faktorfaktor lain yang mungkin tidak termasuk dalam penelitian ini.

\section{Uji t}

\section{Tabel Hasil Uji t}

\begin{tabular}{|c|c|c|}
\hline Variabel & t & Sig. \\
\hline $\begin{array}{c}\text { Karakteristik } \\
\text { Individu }\end{array}$ & $-2,332$ & 0,023 \\
\hline $\begin{array}{c}\text { Karakteristik } \\
\text { Pekerjaan }\end{array}$ & 4,660 & 0,000 \\
\hline
\end{tabular}

Sumber : Data diolah 2020
Dari tabel diatas dapat disimpulkan bahwa nilai signifikan Karakteristik Individu $\left(\mathrm{X}_{1}\right)$ sebesar $0,023<0,05$ maka Ho ditolak dan $\mathrm{Ha}$ diterima yang berarti ada pengaruh signifikan terhadap Komitmen Organisasi Karyawan (Y), sedangkan nilai signifikan Karakteristik Pekerjaan $\left(\mathrm{X}_{2}\right)$ sebesar $0,000<0,05$ maka Ho ditolak dan $\mathrm{Ha}$ diterima yang berarti ada pengaruh signifikan terhadap Komitmen Organisasi Karyawan (Y).

\section{Uji F}

Tabel Hasil Uji F

\begin{tabular}{|c|c|c|}
\hline Model & F & Sig. \\
\hline Regresion & 11,417 & 0,000 \\
\hline \multicolumn{2}{|l|}{ Sumber : Data diolah 2020}
\end{tabular}

Berdasarkan tabel hasil uji $F$ diatas menunjukkan nilai signifikan sebesar $0,000<0,05$ artinya $\mathrm{Ho}$ ditolak dan $\mathrm{Ha}$ diterima. Sehingga dapat disimpulkan bahwa secara simultan Karakteristik Individu $\left(\mathrm{X}_{1}\right)$ dan Karakteristik Pekerjaan $\left(\mathrm{X}_{2}\right)$ berpengaruh signifikan terhadap Komitmen Organisasi Karyawan pada PDAM Lematang Enim Kabupaten Muara Enim.

\section{E. PEMBAHASAN}

Dari hasil perhitungan uji validitas menerangkan bahwa semua item pernyataan yang digunakan untuk mengukur variabel dinyatakan valid, penelitian ini mempunyai $r_{\text {hitung }}$ lebih besar dari $r_{\text {tabel }}$ 0,261. Dari sampel sebanyak 57 Karyawan pada PDAM Lematang Enim Kabupaten Muara Enim.

Dari hasil uji reliabilitas Karakteristik Individu, Karakteristik Pekerjaan, dan Komitmen Organisasi Karyawan masing-masing memperoleh nilai Cronbach Alpha sebesar 0,880, 0,719 , 0,697. Karena semua nilai tersebut $>0,60$, maka dapat 
dinyatakan semua item pernyataan reliable.

Berdasarkan hasil dari regresi linier berganda, yaitu nilai koefisien regresi untuk Karakteristik Individu $\left(\mathrm{X}_{1}\right)$ sebesar -228, nilai koefisien regresi Karakteristik Pekerjaan $\left(\mathrm{X}_{2}\right)$ sebesar 0,507 , dan nilai konstanta sebesar 31,716. Berdasarkan nilai tersebut maka dapat diperoleh persamaan regresi linier berganda $Y=31,716$ $228 \mathrm{X}_{1}+0,507 \mathrm{X}_{2}+\mathrm{e}$ yang artinya apabila Karakteristik Individu $\left(X_{1}\right)$ mengalami kenaikan satuan, maka nilai Komitmen Organisasi Karyawan (Y) mengalami penurunan sebesar 228, dan selanjutnya apabila Karakteristik Pekerjaan $\left(\mathrm{X}_{2}\right)$ mengalami kenaikan satuan, maka nilai Komitmen Organisasi Karyawan (Y) mengalami peningkatan 0,507.

Dari hasil koefisien korelasi memperoleh hasil nilai koefisien pada $R$ sebesar 0,545 yang berarti hubungan variabel Karakteristik Individu $\left(X_{1}\right)$ dan Karakteristik Pekerjaan $\left(X_{2}\right)$ terhadap Komitmen Organisasi Karyawan (Y), yaitu Cukup. Dan hasil koefisien determinasi memperoleh hasil nilai koefisien pada R Square sebesar 0,297 atau 29,7\% dan sisanya (100\% - 29,7\%) 0,703\% atau $70,3 \%$ dipengaruhi oleh faktorfaktor lain yang mungkin tidak termasuk dalam penelitian ini.

\section{a. Pengaruh Karakteristik Individu Terhadap Komitmen Organisasi Karyawan Pada PDAM Lematang Enim Kabupaten Muara Enim}

Dari hasil pengujian hipotesis (Uji t) secara parsial antara variabel Karakteristik Individu $\left(\mathrm{X}_{1}\right)$ terhadap variabel Komitmen Organisasi Karyawan ( $\mathrm{Y}$ ) diperoleh nilai signifikan sebesar $0,023<0,05$. Maka dapat disimpulkan bahwa secara parsial berpengaruh negatif dan signifikan antara Karakteristik Individu terhadap Komitmen Organisasi Karyawan pada PDAM Lematang Enim Kabupaten Muara Enim. Penelitian ini berbeda dengan penelitian terdahulu yang dilakukan oleh Kuhuparuw (2017), dimana Karakteristik Individu berpengaruh positif dan signifikan terhadap Komitmen Organisasi. Hal ini berkaitan dengan pendapat Thoha (2011:34) bahwa karakteristik individu membawa kedalam tatanan organisasi kemampuan, kepercayaan pribadi, pengharapan, kebutuhan, dan pengalaman masalalunya. Melihat dari karakteristik individu seorang karyawan, maka atasan akan lebih mudah menilai setiap karyawan dalam melaksanakan pekerjaan di perusahaan sehingga dapat mencapai komitmen organisasi karyawan yang baik.

\section{b. Pengaruh Karakteristik Pekerjaan Terhadap Komitmen Organisasi Karyawan Pada PDAM Lematang Enim Kabupaten Muara Enim}

Dari hasil pengujian hipotesis (Uji t) secara parsial antara variabel Karakteristik Pekerjaan $\left(\mathrm{X}_{2}\right)$ terhadap variabel Komitmen Organisasi Karyawan $(Y)$ diperoleh nilai signifikan sebesar $0,000<0,05$. Maka dapat disimpulkan bahwa secara parsial berpengaruh positif dan signifikan antara Karakteristik Pekerjaan terhadap Komitmen Organisasi Karyawan pada PDAM Lematang Enim Kabupaten Muara Enim. Penelitian ini sama dengan penelitian terdahulu yang dilakukan oleh Dewi, dkk (2019), dimana Karakteristik Pekerjaan berpengaruh positif dan signifikan terhadap Komitmen Organisasi. Hal ini berkaitan dengan pendapat Bangun (2012:74) analisis pekerjaan adalah 
proses sistematis untuk mengenal karakteristik suatu pekerjaan. Melihat dari karakteristik pekerjaan seorang karyawan, maka atasan lebih mudah untuk melakukan penilaian pekerjaan karyawan pada perusahaan dengan tujuan untuk menghasilkan sebuah pekerjaan yang baik terhadap komitmen organisasi karyawan.

\section{c. Pengaruh Karakteristik Individu Dan Karakteristik Pekerjaan Terhadap Komitmen Organisasi Karyawan Pada PDAM Lematang Enim Kabupaten Muara Enim}

Dari hasil pengujian hipotesis (uji F) secara bersama-sama antara variabel Karakteristik Individu $\left(\mathrm{X}_{1}\right)$ dan variabel Karakteristik Pekerjaan $\left(X_{2}\right)$ terhadap Komitmen Organisasi Karyawan (Y) menunjukkan nilai signifikan sebesar 0,000 $<0,05$ artinya Ho ditolak dan $\mathrm{Ha}$ diterima. Sehingga dapat disimpulkan bahwa secara simultan Karakteristik Individu $\left(\mathrm{X}_{1}\right)$ dan Karakteristik Pekerjaan $\left(\mathrm{X}_{2}\right)$ berpengaruh signifikan terhadap Komitmen Organisasi Karyawan pada PDAM Lematang Enim Kabupaten Muara Enim.

\section{F. KESIMPULAN DAN SARAN \\ 1. Kesimpulan}

Dari analisis data dan pembahasan yang telah dilakukan maka dalam penelitian ini dapat disimpulkan sebagai berikut :

a. Secara parsial ada pengaruh yang signifikan antara Karakteristik Individu terhadap Komitmen Organisasi Karyawan pada PDAM Lematang Enim Kabupaten Muara Enim.

b. Secara parsial ada pengaruh yang signifikan antara Karakteristik Pekerjaan terhadap Komitmen Organisasi Karyawan pada PDAM
Lematang Enim Kabupaten Muara Enim.

c. Secara simultan Karakteristik Individu $\left(\mathrm{X}_{1}\right)$ dan Karakteristik Pekerjaan $\left(X_{2}\right)$ berpengaruh signifikan terhadap Komitmen Organisasi Karyawan pada PDAM Lematang Enim Kabupaten Muara Enim.

\section{Saran}

Berdasarkan dari analisis data dan kesimpulan yang telah dikemukakan, maka penulis ingin memberi saran yang diharapkan menjadi bahan pertimbangan bagi pihak instansi PDAM Lematang Enim Kabupaten Muara Enim sebagai berikut:

a. Untuk meningkatkan sikap yang baik pada karakteristik individu karyawan di perusahaan, yaitu pimpinan harus memberikan pelatihan dan pengetahuan pada karyawan dengan memberikan saran sikap yang baik dalam bekerja dilingkungan perusahaan, agar terciptanya suatu sikap pekerja individu yang bertanggung jawab dalam melaksanakan pekerjaan yang akan diselesaikan.

b. Untuk meningkatkan keterampilan suatu pekerjaan yang berarti di perusahaan pada karakteristik pekerjaan karyawan, yaitu pimpinan harus memberikan arahan pelatihan kerja pada karyawan untuk meningkatkan perusahaan yang maju agar suatu pekerjaan tersebut sangat berarti bagi karyawan terhadap perusahaan.

c. Untuk meningkatkan rasa percaya diri karyawan pada komitmen organisasi karyawan,yaitu pimpinan harus mengadakan sosialisasi dan penambahan wawasan, serta pengawasan pada karyawan untuk berbagi pengalaman yang didapat sesama karyawan terhadap 
perusahaan untuk mencapai sesuatu yang diinginkan.

d. Bagi Peneliti Selanjutnya

Hasil penelitian ini diharapkan agar bermanfaat dan untuk dapat dipelajari sebagai bahan referensi dan bahan tambahan untuk peneliti selanjutnya yang berkaitan dengan pengaruh karekteristik individu dan karakteristik pekerjaan terhadap komitmen organisasi karyawan.

\section{DAFTAR PUSTAKA}

Akbar, Amirul. dkk. 2017. Pengaruh Komitmen Organisasional Terhadap Kinerja (Studi Pada Karyawan PT Pelindo Surabaya). Jurnal Administrasi Bisnis (JAB). Fakultas IImu Administrasi. Universitas Brawijaya. Juni 2017. Vol. 47, No.2.

Bangun, Wilson. 2012. Manajemen Sumber Daya Manusia. Jakarta: Penerbit Erlangga.

Bintoro dan Daryanto. 2017. Manajemen Penilaian Kinerja Karyawan. Yogyakarta: Gava Media.

Dewi, Intan Sonia. dkk. 2019. Pengaruh Karakteristik Pekerjaan dan Komunikasi Interpersonal Terhadap Komitmen Organisasi (Suatu Studi pada Karyawan Toserba Gunasalma Kawali) Business Management and Entrepreneuship Journal. Fakultas Ekonomi Universitas Galuh. Desember 2019. Volume 1, No. 4

Fahmi, Irham. 2014. Manajemen Kepemimpinan Teori dan Aplikasi. Bandung: Alfabeta.
Gunawan, Imam. 2016. Metode Penelitian Kualitatif: Teori dan Praktik. Jakarta: PT Bumi Aksara.

Kuhuparuw, Ventje Jeffry. 2017. Pengaruh Karakteristik Individu dan Kepuasan Kerja Terhadap Komitmen Organisasi Pada PT. Federal International Finance (FIF) Cabang Ambon. Polibisnis. Dosen Politeknik Negeri Ambon Jurusan Administrasi Niaga. April 2017. Volume. 9, No. 1. ISSN 1858-3717.

Robbins dan Coulter. 2010. Management,Tenth Edition. Jakarta: Penerbit Erlangga.

Sariningtyas, Eka Rosita Widya dan Sulistiyani. 2016. Analisis Karakteristik Individu dan Motivasi Intrinsik Terhadap Komitmen Organisasi dengan Kepuasan Kerja Sebagai Variabel Intervening. (Studi Pada PDAM Tirta Mulia Kabupaten Pemalang). Jurnal IImiah Untag Semarang. Dosen Magister Manajemen FEB. Universitas 17 Agustus 1945 Semarang. 2016. ISSN:2302-2752, Vol.5, No.1.

Siregar, Syofian. 2013. Statistik Parametrik Untuk Penelitian Kuantitatif. Jakarta: PT. Bumi Aksara.

Sugiyono. 2016. Metode Penelitian Manajemen. Bandung: Alfabeta.

Sujarweni, V Wiratna. 2019. Metodologi Penelitian Bisnis \& Ekonomi. Yogyakarta: PT. Pustaka Baru.

Sule dan Saefullah. 2010. Pengantar Manajemen. Jakarta: Kencana Prenada Media Group. 
Sutrisno, Edy. 2011. Budaya

Organisasi. Jakarta: Kencana

Prenada Media Group.

Thoha, Mifta. 2011. Perilaku

Organisasi Dasar dan

Aplikasinya. Jakarta: PT.

Rajagrafindo.

Torang, Syamsir. 2016. Organisasi \& Manajemen. Bandung: Alfabeta.

Wibowo. 2016. Manajemen Kinerja.

Jakarta: PT. Rajagrafindo

Persada. 